\title{
The importance of studying inherited hematological disorders in ancient Anatolian populations
}

\author{
Anadoludaki antik topluluklarda kalıtsal hematolojik bozuklukların \\ çalışılmasının önemi
}

\author{
Yeşim Doğan Alakoç${ }^{1}$, Nejat Akar² \\ ${ }^{1}$ Department of Pathology, Faculty of Medicine, Ankara University, Ankara, Turkey \\ ${ }^{2}$ TOBB-Economy and Technology University Hospital, Ankara, Turkey
}

\begin{abstract}
Before analysis of DNA from ancient remains was possible, anthropologists studied evolution and migration patterns using data obtained from population genetic studies on modern populations combined with data obtained from morphological evaluations of ancient remains. Currently, DNA analysis of ancient populations is making a valuable contribution to these efforts. Researchers that perform ancient DNA analysis prefer to study polymorphisms on the $\mathrm{Y}$ chromosome or mitochondrial DNA because the results are easier to statistically evaluate. To evaluate polymorphisms on diploid genomes, which are more informative, only mutations that have been extensively examined in modern populations should be chosen. The most extensively evaluated mutations are those related to prevalent inherited disorders. As such, beta-thalassemia, sickle cell anemia, FVL mutation of globin and the factor V genes are good candidates for DNA studies in ancient populations. These mutations are common in Anatolia, host to many civilizations since the Paleolithic period. This history makes Anatolia a good place for conducting research that could enhance our understanding of human evolution and migration patterns. (Turk J Hematol 2011; 28: 257-63)

Key words: DNA, population genetics, molecular anthropology, factor V G1691A (Leiden), betathalassemia, sickle cell anemia, Anatolia

Received: December 16, 2010

Accepted: December 21, 2010

\section{Özet}

Antik örneklerden DNA elde edilebileceğinin anlaşılmasından önce antropologlar tarih öncesi insan kalıntılarından elde ettikleri bilgilere modern topluluklardan elde edilen populasyon genetiği bulgularını da ekleyerek evrimsel süreçler ve göç yolları ile ilgili yoruma ulaşmaya çalışırlardı. Günümüzde antik topluluklar üzerinde gerçekleştirilebilen DNA analizleri antropologların bu çabasına büyük katkı sağlamaktadır. Uygulamadaki tüm güçlüklere rağmen sağlayacağı önemli bilgi nedeni ile antik DNA analizini uygulamayı seçen birçok bilimadamı istatistiksel olarak sonuçları daha rahat değerlendirildiğinden öncelikle mitokondriyal DNA ve Y kromozomu üzerindeki farklılıklara odaklanmıştır. Bu eğilimin sebebi, diploit genom üzerinde bulunan farklılıkların daha bilgilendirici olmalarına rağmen değerlendirme açısından birçok güçlüğü de beraberinde getirmesidir ve bu sorun ile başa çıabilmek
\end{abstract}


için modern topluluklarda derinlemesine analiz edilmiş mutasyonların tercih edilmesi gerekmektedir. Günümüzde en iyi değerlendirilmiş mutasyonlar yaygın görülen belli kalıtsal bozukluklarla ilişkilendirilmiş olanlardır. Bunların içerisinde hematolojik bozukluklar ile ilişkilendirilen ve evrimsel süreçleri son derece iyi bilinen globin ve faktör $\mathrm{V}$ genlerinde yer alan beta talasemi, orak hücre anemisi ve FVL mutasyonları iyi adaylardır. Bu yüzden paleolitik dönemden itibaren birçok farklı kültüre evsahipliği yapan ve adı geçen mutasyonların yüksek prevalanslarda gözlendiği Anadolu, insan evrimi ve göç yollarının anlaşılması için eşsiz bir kaynak sunmaktadır. (Turk J Hematol 2011; 28: 257-63)

Anahtar kelimeler: DNA, populasyon genetiği, moleküler antropoloji, Factor V, beta-thalassemia, orak hücre anemi, Anadolu

Geliş tarihi: 16 Aralık 2010

Kabul tarihi: 21 Aralık 2010

\section{Introduction}

After Chinese researchers showed that DNA could be preserved in ancient tissues in 1980, 2 subsequent studies were conducted: Higuchi studied Quagga (an extinct horse species) in 1984 and Paabo reported on a 2400-year-old mummy in 1985. These studies are considered the first ancient DNA studies and are acknowledged as the beginning of a new era [1-3]. Although these studies drew immediate interest in ancient DNA research among the scientific community, this novel field of study did not become popular until the advent of the polymerase chain reaction (PCR) technique towards the end of the 1980s. As the PCR technique facilitates work with DNA extracted from ancient samples and enables ancient DNA research to be systematically performed, researchers quickly became aware of the value of studying evolution based on ancient DNA [4,5]. As such, many ancient DNA studies have been conducted during the last 25 years.

Common to all ancient DNA studies is the challenge to obtain undamaged DNA due to the nature of ancient samples [6-10]. The quality of DNA in ancient samples depends on environmental factors and the duration of exposure to them. DNA extracted from ancient samples is both highly degraded and contaminated with PCR inhibitors that are abundant in soil; therefore, the results of studies based on such low-quality samples are generally received with great skepticism [11]. As such, ancient DNA laboratories must use more elaborate measures [12,13]. The development of proper procedures is important for overcoming the challenges posed by ancient DNA analysis. The design of small fragments that contain point mutations has recently gained importance because it is known that only small fragments of approximately 200 bp can be amplified from ancient DNA.

Although ancient DNA analysis is very difficult and the possibility of obtaining significant results is low, interest in ancient DNA analysis continues to increase because the knowledge gained via such analysis has become indispensable in research on ecology and evolution. It has been common practice to gather pieces of information from various fields for analysis in order to better understand migration patterns and evolutionary stages. For instance, anthropologists combine the knowledge gained from human remains and what is known about genetic polymorphisms in contemporary populations to study human history. As systematic ancient DNA analysis is now possible, data from studies on mutations in ancient human populations can make a unique contribution to the field's knowledge base only if such mutations have been thoroughly studied in modern populations [14,15].

\section{Human remains in biological anthropology}

Anthropologists study human biological evolutionary processes and examine anthropogenic differences between living populations. When a skeleton is evaluated, not only will information regarding its age and gender be discerned, but crucial knowledge regarding its dietary habits, cause of death, and health will also be determined. The knowledge gained from individual samples is then evaluated in order to reach conclusions regarding their population. Such data, along with data collected from the same archeological sites regarding the culture and religion of that particular period can be somewhat simulated. Finally, every population examined in detail is compared with another, in terms of their relationship, which helps researchers understand the dynamics of a particular period [16]. 
An important aspect of anthropological research is the examination of the signs indicative of a skeleton's state of health; however, this can only be determined if there are obvious signs left in bones or teeth [17-19]. When skeletal signs of morbidity are detected, its origin, its distribution within the skeleton's group or modern populations, and the skeleton's dietary habits can be evaluated. Moreover, if the morbidity being studied is inherited, genetic links between human populations and evolutionary pressures that have played a role in the inheritance of the mutation up to the present can also be included in the analysis.

Although it provides valuable data, evaluation of phenotypes reflected in bones is difficult for anthropologists. The most common difficulty for anthropologists is that bone pathologies may also be due to environmental conditions that trigger clinical signs. Porotic hyperostosis related to iron deficiency anemia can also occur in other types of noninherited anemias in agricultural populations in which the consumption of fat is low, but that of grain is high [20]. This is why DNA analysis is necessary for understanding whether or not a condition is inherited [21]. DNA analysis is crucial for pinpointing a disease-related mutation in an ancient population, comparing this information with that of other ancient and modern populations from the same geographic region, evaluating the genetic similarity of these populations, and for understanding the environmental pressures that played a role in preserving the mutation. Studying the spread of mutations in the past and their modern prevalence make it possible to understand how they have been subjected to natural selection and to gather data on migration patterns [15].

\section{Molecular anthropology and inherited hematologic disorders}

Molecular anthropology uses anthropologic and molecular genetic data to discern the evolutionary link between ancient and modern populations, and to determine human migration patterns. For instance, examination of DNA polymorphisms is a common method used to study the history of human evolution. The entire genome has polymorphic sites, but use of polymorphism data obtained from the chromosome $\mathrm{Y}$ and mitochondrial DNA is preferred. Although the diploid genome provides more information when interpreted accurately, as interpretation of data obtained from diploid genome studies is difficult researchers are reluctant to use diploid genome data in population genetics [22]. To facilitate interpretation of diploid genome study results it is crucial to choose mutations whose molecular genetics and evolutionary stages are well known.

According to modern genetics theory there are 5 factors that can affect gene frequency: selection, mutation, genetic drift, gene flow, and selective mating. As such, any study that aims to determine the spread of an allele should consider all 5 factors. An allele concerning a particular situation can be among the population founders, can be independently introduced from outside the population structure after the population has been established, or can be mixed in the population structure due to genetic contact with a neighboring population. If the mutation frequently occurs in different populations, its origin can be determined by evaluating the mutation and simultaneously inherited haplotypes. Such genetic variations as haplotypes provide valuable information for tracing migration patterns, determining an individuals' geographic origin, and establishing connections within populations [23].

The spread of genetic variations, some of which cause genetic diseases, varies worldwide; however, some similarities can be observed in the frequency of these mutations and their haplotypes within populations that interacted during a particular period and/or shared geographic locations [24]. As such, studies on the frequency and carriage percentage of particular mutations can provide additional data concerning connections between populations [25]. Moreover, the prevalence of a specific disease-related mutation in populations can be determined and how the processes of population genetics might possibly have affected the prevalence can be examined. Haplotypes carried with a mutation are used to identify such as factors migration, genetic drift, and natural selection that affected the frequency of the mutation. Not only does haplotype analysis frequently enable the history of a mutation to be reconstructed, it also provides information about how often and when its frequency was altered, and in which populations the mutation first existed [26]. Accordingly, despite its symptoms-including the risk of mortality-the widespread 
prevalence of a mutation can be explained by various genetic factors in different populations [27]; therefore, mutations that have been extensively studied in modern populations must also be examined in ancient populations, as they can provide useful data on genetic relationships. The mutations that appeal to research most are generally those related to certain genetic disorders and those that maintain their frequency despite their negative affects on health. Thus, beta-thalassemia, sickle cell anemia, and Factor V G1691A (Leiden) (FVL) mutations are examples of the most extensively studied mutations [28-30].

The malaria hypothesis is considered to be a crucial starting point in determining the factors that affect the prevalence of hemoglobinopathies, common and heterogeneous worldwide [26]. The geographic distribution of malaria and hemoglobinopathies overlap to a great extent. It is likely that the malaria parasite has coexisted with modern humans for ages; however, malaria is thought to have become widespread approximately 10,000 years ago in Levant and in Asia. The high prevalence of this parasite is thought to have originated with the development of agriculture.

Agricultural activities first put an end to the scarcity of food, which was the most important factor controlling population growth. Consequently, this resulted in rapid population growth and diseases replaced the scarcity of food as the primary factor controlling population growth. While creating space for agricultural activities humans destroyed vegetation and fauna, and altered the balance of the environment. This process caused many mammals to become extinct and many parasites to lose their hosts; as a result, such parasites began infecting the expanding human population [27]. In populations affected by malaria, a high frequency of hemoglobinopathies-including sickle cell anemia and thalassemia-has been noted [31,32]. It is plausible to conclude that their heterozygous carriers are resistant to malaria; however, although there is considerable geographic overlap between these mutations and malaria, in the case of beta-thalassemia the correlation is not as straightforward as in the case of sickle cell anemia [33]. Beta-thalassemia is widespread in subtropical malarial, Mediterranean, and Middle Eastern regions; however, it also exists in some non-malarial regions. As such, the existence of another evolutionary process alongside the advantage brought by heterozygocity appears to be likely.

Another well known mutation, factor V Leiden (FVL), which increases the risk of thrombosis 80 -fold when homozygotic, is a common monogenic disorder. Its worldwide distribution is highly heterogeneous and exhibits remarkable ethnic diversity. While polymorphism ranging from $1 \%-8.5 \%$ is present in Europeans, Jews, Israel-Arabs, and Indians, it is non-existent in African blacks, Chinese, Japanese, and indigenous South Americans [34-38]. Limited and ethnic distribution of FVL suggests that the mutation originated from a single source, most probably Europeans or Neolithic farmers along the migratory path.

During the Neolithic period about 10,000 years ago farming spread to Northern Europe from the Middle East. The distribution of FVL followed a similar pattern, suggesting that the distribution is due to Neolithic migration. Furthermore, the army of Alexander the Great is thought to have contributed to the distribution of FVL [39]. Evolutionary hypotheses regarding the distribution of FVL suggest the possibility that heterozygosity may have been a selective advantage. In the past, deaths resulting from sepsis and bleeding during pregnancy and birth accounted for $10 \%$ of all deaths. It seems highly plausible that a mutation preventing bleeding may have provided a selective advantage [40]. Haplotype analysis of FVL suggests that the founder effect may have influenced distribution of the mutation and the advent of the mutation can be traced back 21,000 years. The origin of Caucasians among which the mutation is prevalent can be traced back 40,000 years. This historical fact coincides with the claim that FVL mutation first occurred in a Caucasian ancestor 21,000 years ago [41]. A study on population genetics of the mutation shows that during the Neolithic period FVL in Europe probably spread from Anatolia (Turkey) [42].

\section{Why Anatolia?}

Anatolia, due to its favorable geographic and strategic location, has been home to numerous civilizations since the Paleolithic period [43]. Its geographic location-bridging continents-has been an important passage for numerous species, including humans. This has made Anatolia a pre- 
cious region for biodiversity. While Anatolia offered many advantages for its inhabitants, it was also suitable for malaria due to its wetlands. This resulted in a high frequency of beta-thalassemia and sickle cell anemia, which in turn provided protection against malarial epidemics, once a severe threat in the Mediterranean region [43-50]. FVL, another mutation that probably originated in Anatolia 21,000 years ago, is also highly prevalent in this region $[44,45]$.

In Anatolia a number of mutations that have been extensively examined, in terms of molecular genetics and population genetics, occur frequently, offering a uniquely valuable source for identifying genetic markers in ancient populations. Distinguishing and analyzing the layers of population history in this region in which various populations have been fighting, immigrating, trading and praying to different Gods for centuries is a challenging task. As such, molecular techniques can aid in the analysis of ancient communities; however, only a few studies have examined genetic diseases at the molecular level in ancient populations, though they reported valuable results.

In 1995 Filon performed DNA analysis of a child's skeleton that was thought to have had porotic hyperostosis due to iron deficiency anemia and reported the existence of beta-thalassemia-related mutation. As a result, he was able to show that data related to ancient populations, which earlier could not be obtained, could be obtained via DNA experiments [21,49]. The same year Beraud-Colomb et al. extracted DNA from skeletal remains belonging to different years and evaluated various polymorphisms on the globin gene using skeletal DNA [15]. The only similar study in Anatolia was performed by our group in 2009 using 3000-year-old Urartian tooth samples excavated from a site in Anatolia. DNA samples extracted from these teeth were screened using real time PCR to detect FVL mutation and 1 of the samples, which was previously determined to be male, was heterozygotic $[51,52]$.

\section{Conclusion}

Anatolia is a fertile land suitable for agriculture and has always appealed to scientists due to the richness of its biodiversity and the vast number of its ancient populations. A significant number of histori- cal excavations in this region have been performed by non-Turkish scientists, and therefore DNA analysis on ancient materials have been conducted abroad [53,54]; however, we think it is important that such results be evaluated by scientists with knowledge about the modern Anatolian population. Mutations with a high frequency in modern populations have a heterogeneous distribution in Anatolia as well as in other parts of the world; therefore, for the study of sickle cell anemia mutation in ancient populations, excavations closer to Mersin, Tarsus, Adana, and Hatay, Anatolian regions in which the mutation currently has a high frequency, will increase the probability of identifying this mutation and make it possible to compare its frequency in ancient and modern populations. As such, additional research may provide an abundance of data on the genetic background of Anatolian populations.

\section{Conflict of interest statement}

The authors of this paper have no conflicts of interest, including specific financial interests, relationships, and/or affiliations relevant to the subject matter or materials included.

\section{References}

1. Hummel S. Ancient DNA Typing; methods, strategies and applications. Springer-Verlag Berlin Heidelberg 2003; pp. 209-11.

2. Higuchi R, Bowman B, Freiberger M, Ryder OA, Wilson AC. DNA sequences from the quagga, an extinct member of the horse family. Nature 1984;312:282-4. [CrossRef]

3. Pääbo S. Molecular cloning of Ancient Egyptian mummy DNA. Nature 1985;314:644-5. [CrossRef]

4. Wayne RK. Full of Sound and Fury; The recent history of ancient DNA. Annu Rev Ecol Syst 1999;30:457-77. [CrossRef]

5. Gilbert MT, Bandelt HJ, Hofreiter M, Barnes I. Assessing ancient DNA studies. Trends Ecol Evol 2005;20:541-4. [CrossRef]

6. Hagelberg E, Clegg JB. Isolation and characterization of DNA from archaeological bone. Proc Biol Sci 1991;244:45-50. [CrossRef]

7. Rohland N, Hofreiter M. Ancient DNA extraction from bones and teeth. Nat Protoc 2007;2:1756-62. [CrossRef]

8. Yang DY, Eng B, Waye JS, Dudar JC, Saunders SR. Technical note: improved DNA extraction from ancient bones using silica-based spin columns. Am J Phys Anthropol 1998;105:539-43. [CrossRef]

9. Hanni C, Brousseau T, Laudet V, Stehelin D. Isopropanol precipitation removes PCR inhibitors from ancient bone extracts. Nucleic Acids Res 1995;23:881-2. [CrossRef] 
10. Alakoc YD, Aka PS. "Orthograte entrance technique" to recover DNA from ancient teeth preserving the physical structure. Forensic Sci Int 2009;188:96-8. [CrossRef]

11. Meyer E, Wiese M, Bruchhaus H, Claussen M, Klein A. Extraction and amplification of authentic DNA from ancient human remains. Forensic Sci Int 2000;113: 87-90. [CrossRef]

12. Handt O, Hoss M, Krings M, Pääbo S. Ancient DNA: methodological challenges. Experientia 1994;50:524-9. [CrossRef]

13. Yang DY, Watt K. Contamination controls when preparing archaeological remains for ancient DNA analysis. J Archaeol Sci 2005;32:331-6. [CrossRef]

14. Malmström H. Ancient DNA as a means to investigate the European Neolithic. Acta Universitatis Upsaliensis Uppsala. Digital Comprehensive Summaries of Uppsala Dissertations from the Faculty of Science and Technology. 323pp.

15. Beraud-Colomb E. Human beta globin gene polymorphism characterized in DNA extracted from ancient bones 12000 years old. Am J Hum Genet 1995;57: 1267-74.

16. Brothwell DR. Digging up bones: the excavation, treatment, and study of human skeletal remains. Cornell University Press, 1981.

17. Homøe P, Lynnerup N, Skovgaard LT, Rasmussen N. Estimation of otitis media in ancient populations. A study of past and present Greenlandic Inuit. J Laryngol Otol 1996;110:1114-9.

18. Stuart-Macadam P. Porotic hyperostosis: new evidence to support the anemia theory. Am J Phys Anthropol 1987;74:521-6. [CrossRef]

19. Tayles N. Anemia, genetic diseases, and malaria in prehistoric mainland Southeast Asia. Am J Phys Anthropol 1996;101:11-27. [CrossRef]

20. Weaver DS. An osteological test of changes in Subsistence and settlement patterns at Casas Grandes, Chihuahua, Mexico. American Antiquity 1981;46:361-4. [CrossRef]

21. Filon D, Faerman M, Smith P, Oppenheim A. Sequence analysis reveals a beta-thalassaemia mutation in the DNA of skeletal remains from the archaeological site of Akhziv, Israel. Nat Genet 1995;9:365-8. [CrossRef]

22. Harding RM, Fullerton SM, Griffiths RC, Bond J, Cox MJ, Schneider JA, Moulin DS, Clegg JB. Archaic African and Asian Lineages in Genetic Ancestry of Modern Humans. Am J Hum Genet 1997;60:772-89.

23. Oddoux C, Guillen-Navarro E, Ditivoli C, Dicave E, Cilio MR, Clayton CM, Nelson H, Sarafoglou K, McCain N, Peretz H, Seligsohn U, Luzzatto L, Nafa K, Nardi M, Karpatkin M, Aksentijevich I, Kastner D, Axelrod F, Ostrer H. Mendelian diseases among Roman Jews: implications for the origins of disease alleles. J Clin Endocrinol Metab 1999;84:4405-9. [CrossRef]

24. Collins FS. What we do and don't know about 'race', 'ethnicity', genetics and health at the dawn of the genome era. Nat Genet 2004;36:13-5. [CrossRef]

25. Shpilberg O, Peretz H, Zivelin A, Yatuv R, Chetrit A, Kulka T, Stern C, Weiss E, Seligsohn U. One of the two common mutations causing factor XI deficiency in Ashkenazi Jews (type II) is also prevalent in Iraqi Jews, who represent the ancient gene pool of Jews. Blood 1995;85:429-32.

26. Flint J, Harding RM, Clegg JB, Boyce AJ. Why are some genetic diseases common? Distinguishing selection from other processes by molecular analysis of globin gene variants. Hum Genet 1993;91:91-117.

27. Flint 1998. The population genetics of the heamoglobinopathies. Bailliere's Clinical Heamotology 1998; $11: 1$.

28. Currat M, Trabuchet G, Rees D, Perrin P, Harding RM, Clegg JB, Langaney A, Excoffier L. Molecular analysis of the beta-globin gene cluster in the Niokholo Mandenka population reveals a recent origin of the beta(S) Senegal mutation. Am J Hum Genet 2002;70:207-23. [CrossRef]

29. Fullerton SM, Harding RM, Boyce AJ, Clegg JB. Molecular and population genetic analysis of allelic sequence diversity at the human beta-globin locus. Proc Natl Acad Sci 1994;91:1805-9. [CrossRef]

30. Das SK, Talukder G. A review on the origin and spread of deleterious mutants of the beta globin gene in Indian Populations. Homo 2001;52:93-109. [CrossRef]

31. Livingstone FB. Anthropological Implications of sickle cell gene distribution in West Africa. Am Anthropol 1958;60:533-62. [CrossRef]

32. Hershkovitz I, Ring B, Speirs M, Galili E, Kislev M, Edelson G. Possible congenital hemolytic anemia in prehistoric coastal inhabitants of Israel. Am J Phys Anthropol 1991;85:7-13. [CrossRef]

33. Charmot-Bensimon D. Human globin genes: what can we learn from their polymorphism? Bull Soc Pathol Exot 1999;92:242-8.

34. Hooper WC, Dilley A, Ribeiro MJA, Benson J, Austin H, Silva V, Rawlins P, Wenger NK, Evatt BL. A racial difference in the prevalence of Arg506 Gln mutation. Thromb Res 1996;81:577-81. [CrossRef]

35. Herrmann FH, Koesling M, Schrŏder W, Altman R, Jiménez Bonilla R, Lopaciuk S, Perez-Requejo JL, Singh JR. Prevalence of factor V Leiden mutation in various populations. Genet Epidemiol 1997;14:403-11. [CrossRef]

36. Gregg JP, Yamane AJ, Grody WW. Prevalence of the factor V-Leiden mutation in four distinct American ethnic populations. Am J Med Genet 1997;73:334-6. [CrossRef]

37. Franco RF. Heterogeneous ethnic distribution of factor v leiden mutation. Genet Mol Biol 1999;22:143-5. [CrossRef]

38. Bauduer F, Lacombe D. Factor V Leiden, prothrombin 20210A, methylenetetrahydrofolate reductase 677T, and population genetics. Mol Genet Metab 2005;86:91-9. [CrossRef]

39. Pawar AR, Shetty S, Ghosh K, Mohanty D. How old is factor $\mathrm{V}$ Leiden mutation? Thromb Haemost 2001;86:1591-2. 
40. Lindqvist PG, Dahlbäck B. Carriership of Factor V Leiden and evolutionary selection advantage. Curr Med Chem 2008;15:1541-4. [CrossRef]

41. Zivelin A, Griffin JH, Xu X, Pabinger I, Samama M, Conard J, Brenner B, Eldor A, Seligsohn U. A single genetic origin for a common Caucasian risk factor for venous thrombosis. Blood 1997;89:397-402.

42. Lucotte G, Mercier G. Population genetics of factor V Leiden in Europe. Blood Cells Mol Dis 2001;27:362-7. [CrossRef]

43. Kuhn SL. Paleolithic Archeology in Turkey. Evol Anthropol 2002;11:198-210. [CrossRef]

44. Akar N. Factor V 1691 G-A mutation distribution in a healthy Turkish population. Turk J Hematol 2009;26:9-11.

45. Gürgey A, Mesci L. The prevalence of factor V Leiden (1691 G-->A) mutation in Turkey. Turk J Pediatr 1997;39:313-5.

46. Aksoy M, Lehmann H. Sickle-cell-thalassemia disease in South Turkey. Br Med J 1957;1:734-8. [CrossRef]

47. Koçak R, Alparslan ZN, Ağridağ G, Başlamisli F, Aksungur $\mathrm{PD}$, Koltaş S. The frequency of anaemia, iron deficiency, hemoglobin $\mathrm{S}$ and beta thalassemia in the south of Turkey. Eur J Epidemiol 1995;11:181-4. [CrossRef]

48. Akar E, Akar N. A review of abnormal hemoglobins in Turkey. Turk J Hematol 2007;24:143-5.
49. Tadmouri GO, Tüzmen S, Ozçelik H, Ozer A, Baig SM, Senga EB, Başak AN. Molecular and population genetic analyses of beta-thalassemia in Turkey. Am J Hematol 1998;57:215-20. [CrossRef]

50. Aksoy M. Hemoglobinopathies in Turkey. Hemoglobin 1985;9:209-16. [CrossRef]

51. Oner R, Altay C, Gurgey A, Aksoy M, Kilinç Y, Stoming TA, Reese AL, Kutlar A, Kutlar F, Huisman TH. Betathalassemia in Turkey. Hemoglobin 1990;14:1-13. [CrossRef]

52. Alakoc Y D, Aka PS, Eğin Y, Akar N. Factor V Leiden in an Urartian, Dating back to 1000 BC. Clin Appl Thromb Hemost 2010;16:679-83. [CrossRef]

53. Arndt A, Van Neer W, Hellemans B, Robben J, Volckaert F, Waelkens M. Roman trade relationships at Sagalassos (Turkey) elucidated by ancient DNA of fish remains. J Archaeol Sci 2003;30:1095-105. [CrossRef]

54. Jehaes E, Waelkens M, Muyldermans A, Cassiman J, Smits E, Poblome J, Lambrecht, P, Decorte R. DNA analysis of archaeological human remains from Sagalassos. In: Sagalassos V: report on the survey and excavation campaigns of 1996 and 1997. Leuven university press 2000;821-31. 